\title{
'Central' Actions of Corticosteroid Signaling Suggested by Constitutive Knockout of Corticosteroid Receptors in Small Fish
}

\author{
Tatsuya Sakamoto * and Hirotaka Sakamoto \\ Ushimado Marine Institute, Faculty of Science, Okayama University, 130-17, Kashino, Ushimado, \\ Setouchi 701-4303, Japan; hsakamo@okayama-u.ac.jp \\ * Correspondence: ryu@uml.okayama-u.ac.jp; Tel.: +81-869-34-5210
}

Received: 4 February 2019; Accepted: 11 March 2019; Published: 13 March 2019

check for updates

\begin{abstract}
This review highlights recent studies of the functional implications of corticosteroids in some important behaviors of model fish, which are also relevant to human nutrition homeostasis. The primary actions of corticosteroids are mediated by glucocorticoid receptor (GR) and mineralocorticoid receptor (MR), which are transcription factors. Zebrafish and medaka models of GR- and MR-knockout are the first constitutive corticosteroid receptor-knockout animals that are viable in adulthood. Similar receptor knockouts in mice are lethal. In this review, we describe the physiological and behavioral changes following disruption of the corticosteroid receptors in these models. The GR null model has peripheral changes in nutrition metabolism that do not occur in a mutant harboring a point mutation in the GR DNA-binding domain. This suggests that these are not "intrinsic" activities of GR. On the other hand, we propose that integration of visual responses and brain behavior by corticosteroid receptors is a possible "intrinsic" / principal function potentially conserved in vertebrates.
\end{abstract}

Keywords: metabolism; behavior; brain; vision; glucocorticoid; mineralocorticoid

\section{Introduction}

Soon after the discovery of the steroid hormone receptor, establishment of its neuroanatomical localization [1-3] laid the groundwork for understanding that the brain, similarly to peripheral tissues, is a target organ for steroid hormones [4]. In the brain, receptors for corticosteroids, glucocorticoids (GR), and mineralocorticoids (MR) can act through a classic, genomic mechanism to elicit changes in behavior and physiology, and these receptors can further function at the membrane to activate cytoplasmic signaling pathways $[5,6]$. Besides the general metabolic functions, this review will focus on integration of visual and brain behavioral responses as a principal function of corticosteroid signaling, based on recent development of the first constitutive knockouts of GR and MR in small fish, since such functions appear to be conserved in vertebrates, including humans [7], and may be important for nutrition homeostasis.

\section{A Conserved Principal Function of Corticosteroid Signaling Indicated by Receptor-Knockout Small Fish}

In this section, we will describe physiological and behavioral (Table 1) changes associated with constitutive knockouts of GR and MR to provide a novel framework in which to explore implications for food intake and nutrition homeostasis. 
Table 1. Phenotypic consequences including those associated with nutrition dysregulation in constitutive knockouts of glucocortoid receptor (GR) and mineralocorticoid receptor (MR).

\begin{tabular}{|c|c|c|c|c|c|c|c|c|c|c|}
\hline Mutant Line & Survival & Morphology & Fat Deposition & Glucose Metabolism & $\begin{array}{c}\text { Immune } \\
\text { Responses }\end{array}$ & Osmo-Regulation & HPA Axis & Anxiety & $\begin{array}{c}\text { Visual-Regulated } \\
\text { Behavior }\end{array}$ & References \\
\hline GR Knockout & - & $\begin{array}{l}\text { - development of } \\
\text { heart and intestine }\end{array}$ & + & $\begin{array}{l}\text { - hypoxia-inducible } \\
\text { factor }\end{array}$ & - & \pm in fresh water & $\begin{array}{c}\text { - negative } \\
\text { feedback }\end{array}$ & & - & [8-10] \\
\hline $\begin{array}{c}\text { GR DNA } \\
\text { Binding Mutant }\end{array}$ & - & \pm & & $\begin{array}{l} \pm \text { hypoxia-inducible } \\
\text { factor }\end{array}$ & - & \pm in fresh water & $\begin{array}{c}\text { - negative } \\
\text { feedback }\end{array}$ & + & $\begin{array}{c}\text { - visual adaptation } \\
\text { in retina }\end{array}$ & {$[11,12]$} \\
\hline MR Knockout & \pm & \pm & & & & $\begin{array}{c} \pm \text { in fresh water } \\
\text { and seawater }\end{array}$ & $\begin{array}{c}\text { - negative } \\
\text { feedback }\end{array}$ & & - & {$[10,13,14]$} \\
\hline
\end{tabular}

Abbreviations: $+=$ increase; $-=$ decrease; $\pm=$ no change compared to control fish. Blank columns indicate "not examined". 


\subsection{Glucocortoid Receptor (GR) Knockout}

Knockout approaches in mice have been used to study the roles of GR [15]. However, death occurs after a few hours in homozygous GR-knockout mice [16]. Survival to adulthood is observed for heterozygotes or conditional knockouts, and these mice can be used to study the physiological, endocrine, and behavioral details of GR signaling [15-17].

\subsubsection{Glucocortoid Receptor (GR) DNA Binding Mutant}

A zebrafish mutant harboring a point mutation in the GR DNA-binding domain has no transcriptional activity of GR but is adult-viable [11]. This was a key finding; the homozygous mutant fish cannot be distinguished morphologically from wild type in fresh water. This suggests that hyperosomoregulation is similar to that in wild-type zebrafish, although survival is reduced by $70 \%$ compared with wild type and immune function is suppressed [8]. However, placement of the mutant fish in an aquarium that is unfamiliar causes them to become immobile and have reduced exploratory behavior, with no habituation to this stress after repeated exposure. Normal behavior can be restored by treatment with fluoxetine, an antidepressant, or 'visual' interactions with wild-type fish. These findings suggest an essential link of glucocorticoid signaling, not only to the stress response, but also to regulation of affective disorders [11].

Brain GRs can consistently be considered to be important for regulating hypothalamus-pituitary-adrenal (HPA) axis function independent of pituitary GR activity in mouse models, and the heterozygotic [16] or forebrain-restricted [18] GR knockout also causes depressive behaviors. In contrast, anxiety is reduced or there are no measurable behavioral effects in mice with total neuronal or glial GR knockout [19] and antisense GR knockdown [20]. However, a transgenic mouse with forebrain GR overexpression had increased anxiety and depressive behavior [21]. The inconsistency of the behavioral results in mice may have occurred because manipulations that are tissue-restricted give incomplete or complicated effects [17]. Such mouse behavior is at best correlated moderately with human affective disorder symptoms, but GR can be thought to contribute to the behavior characteristics of anxiety, despair, and learning phenotypes [15].

Visually regulated behavior in the zebrafish mutant described above [11] was abolished by darkness and slowly recovered after light exposure [12]. The mutant had reduced photoresponsiveness of the dark-adapted retina, and delayed readaptation to light. Genes associated with dopaminergic signaling were among several that were dysregulated in the mutant [22-24]. These results suggest that glucocorticoids in zebrafish may regulate visual function by controlling the retinal gene network needed for visual adaptation, and this appears to be conserved through vertebrates [25]. This function occurs in addition to the commonly recognized effect of reverse signaling, in which light perception influences glucocorticoid production via functional connections of the retina to the HPA axis [26].

\subsubsection{Glucocortoid Receptor (GR) CRISPR (clustered regularly interspaced short palindromic} repeats) Mutant

Facchinello and colleagues [8] generated a CRISPR-induced null mutant of the GR gene. This mutant zebrafish can grow, but survival decreases by $50 \%$ compared with wild type. Development of the heart and anterior intestine is impaired, and the fish exhibit increased fat deposition, as also seen in Cre recombinase driver transgenic mice with metabolism-associated tissue-specific knockout [17]. In addition, mice with GR knockout in skeletal muscle are protected against muscle wasting caused by elevated endogenous glucocorticoids, which is related to nutritional deprivation [27-29]. Disruption of glucocorticoid signaling in osteoblasts also prevented weight gain and altered glucose and insulin sensitivity in a mouse model [30], showing that GR in the musculoskeletal system also regulates the systemic energy supply [31]. However, cross-talk between the related transcriptional regulators, rather than the established transcriptional route for GR, may be needed for at least some changes in glucose metabolism in the zebrafish liver, which is an important regulator of blood glucose, since transcriptional responses of GR-dependent hypoxia-inducible factors that regulate 
gluconeogenesis/glycogen synthesis are also activated in the GR DNA-binding mutant zebrafish [11]; no direct comparison of the effects of the two GR mutants on glucose metabolism, fat metabolism or depressive behavior had been reported. Additionally, transcriptional activity linked to immune response appears to be hampered worse in the GR CRISPR mutant than in the DNA-binding mutant [8].

The glucocorticoid-mediated hyperactivity to a light stimulus in larvae is also abolished in a zebrafish GR null mutant, in addition to the hypercortisolemic response and the absence of a cortisol stress response [10].

\subsection{MR Knockout}

MR knockout mice experiments have produced several findings [32]. Constitutive MR knockout mice [33] survive only to about postnatal day 10, and have conditions such as increased plasma renin, angiotensin II, aldosterone (pseudohypoaldosteronism), hyperkalemia, and hyponatremia. Rescue is possible by exogenous salt administration [34], but difficulty with salt balance continues, with chronic activation of the renin-angiotensin system. These effects cause difficulty in studying these mice, and MR signaling has mainly been studied using mouse lines with conditionally altered expression or function of MR [32].

We recently established a medaka null mutant of the MR gene that grows and adapts to seawater and fresh water [13]. This corresponds to the idea that MR is not involved in body fluid regulation in fish. However, our study of behavioral phenotypes based on the central MR localization (Figure 1) showed these knockout medaka cannot track moving black dots, despite having increased swimming acceleration [13]. Thus, MR is needed for normal motion as the fish responds to visual stimuli, but not for recognition of these stimuli per se. Larval hyperactivity to a light stimulus is also abolished in a zebrafish null mutant of the MR gene, in addition to a delayed but sustained cortisol response to a post-stressor [10].

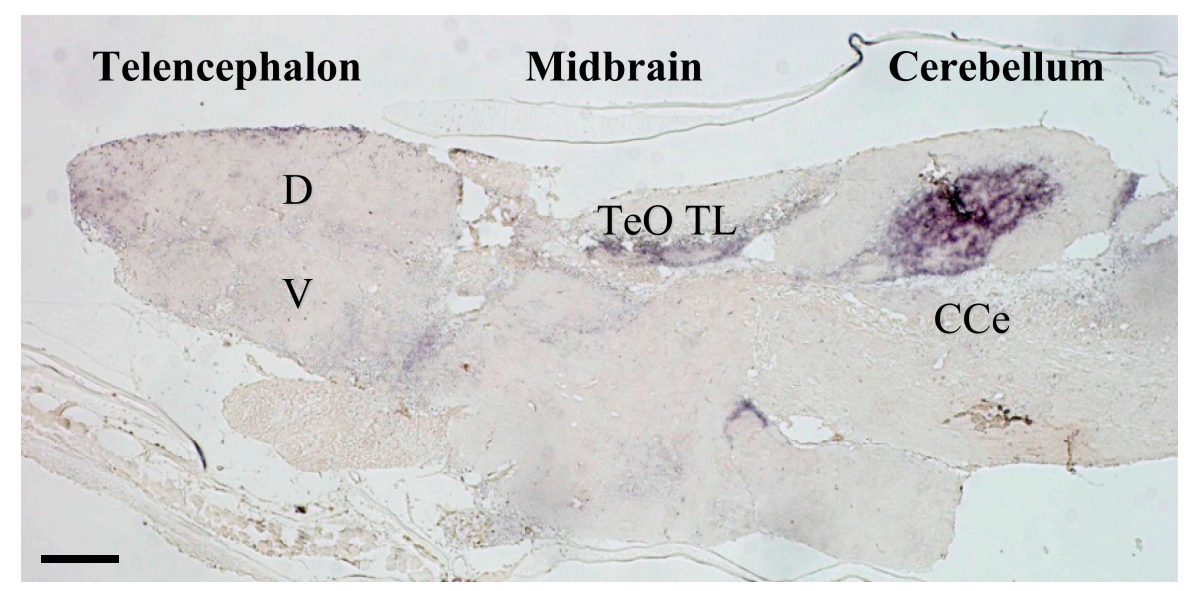

Figure 1. Photomicrograph of mineralocorticoid receptor (MR) in-situ hybridization in medaka brain. MR expression is restricted to a number of important areas that likely correspond to homologous brain regions containing MR in other vertebrates including those of humans [35]. Telencephalic regions exhibiting higher MR expression include the ventral parts of the lateral zone of the dorsal telencephalon (putative fish homologue of the mammalian hippocampus [36]), and commissural and subcommissural nuclei of the telencephalon ( $\mathrm{V}$; putative fish homologue to the mammalian amygdala) [36]. In the diencephalon, the hypothalamic preoptic area, inferior lobe of the hypothalamus, and glomerulus complex of the thalamus exhibit MR expression, as do the mesencephalic tegmentum and granular layer of the optic tectum. MR expressed markedly in some regions of the cerebellum. CCe, corpus cerebelli; $\mathrm{D}$, dorsal telencephalic area; $\mathrm{TeO}$, tectum opticum; TL, torus longitudinalis; V, ventral telencephalic area. The detailed expression profiles are described in Sakamoto et al. [13]. Ubiquitously expressed GR in the brains of rodent and fish, as well as MR expression in the rodent brain, have been illustrated elsewhere [15,37,38]. Scale bar: $100 \mu \mathrm{m}$. 
Medaka with MR have induced GR expression in the eyes and brain, but not in osmoregulatory organs [14]. This shows that glucocorticoid signaling, and not mineralocorticoid signaling, is important in body fluid regulation of the fish [13,39]. GR is activated by cortisol and cortisone, but not 11-deoxycorticosterone, whereas MR is activated by 11-deoxycorticosterone and cortisol, but not cortisone [40]. Therefore, as mostly found in the mammalian brain [41], cortisol is an MR agonist only in tissues without substantial activity of $11 \beta$-hydroxysteroid dehydrogenase type 2 , which converts cortisol to cortisone [42]. The cellular localization of $11 \beta$-hydroxysteroid dehydrogenase in the fish brain is unclear [43], but cortisol-GR might compensate for a lack of cortisol-MR, rather than of 11-deoxycorticosterone-MR. Thus, this GR expression suggests that MR knockout phenotype is due to the loss of 11-deoxycorticosterone-MR.

In neuroendocrine functions of stress, anxiety, and cognition, MR has key roles, as also shown in mouse with conditionally altered expression of MR and in mammals using MR antagonists [15,32,44]. Blockade or knockout of brain MR damages memory and the HPA axis [33,45-53], whereas transgenic MR overexpression in forebrain reduces anxiety in mice [54]. Functions of MR mediated by the eyes have not been analyzed by disruption of MR in a mouse model. Cre recombinase driver transgenic mice, which are more tightly regulated, allow temporal induction by doxycycline or tamoxifen, for example, in different life-cycle phases, and they are needed for transgenic studies. These studies may provide more information on the corticosteroid receptor functions.

\section{Association with Nutrition and Perspectives}

Impaired vision-/brain-dependent behavior observed in zebrafish corticosteroid-receptor mutants might cause the defects in behavior of MR-knockout medaka upon exposure to visual stimuli. This mechanism might further regulate corticosteroid-receptor neuroendocrine functions which is well known to be controlled by light/visual perception [55], and the modulation of HPA function may particularly affect food intake and energy homeostasis [15]. A less dissipative metabolism for low stress responsiveness is often associated with fattening [56]. Regardless, our results may indicate a principal function of corticosteroids that is conserved in vertebrates. Corticosteroids may integrate the HPA axis and limbic system with the visual physiology of the sensory periphery, in a coping mechanism for adjustment of the whole organism to rapid changes in environmental conditions, such as visual stimuli. Thus, the fish models described here provide a unique opportunity for identification of corticosteroid-regulated important networks conserved in vertebrates, including humans.

The null mutant of the GR gene has some peripheral changes in metabolism. However, recent evidence demonstrating transcriptional activation of associated GR-dependent genes in the GR DNA-binding mutant suggests that regulation of expression of these genes by GR is not DNA binding-dependent (is not due to "intrinsic" activities of GR) and that such noncanonical, more complex regulation that is widely conserved in human nutrition metabolism requires additional mutational studies $[9,57,58]$. Targeted genome editing technology permits high-throughput manipulation of corticosteroid receptor-binding sites in transcriptional regulatory regions or protein interaction domains associated with transcriptional regulatory complexes. This technology has been used in several species and may improve knowledge of corticosteroid signaling in human nutrition metabolism $[59,60]$. Identification and targeting the primary transcripts of corticosteroid receptors will allow determination of the associated regulatory networks. This understanding of signaling mechanisms in human nutrition homeostasis may then lead to new therapies.

The terms "glucocorticoid" and "mineralocorticoid" originate from classical studies in mammals but use of these terms is questionable for all vertebrates. This is based on the essential corticosteroid role in integration of visual responses with brain-dependent behaviors in fish. For example, "glucocorticoid" functions may not be "intrinsic" activities of GR, and mammalian renal mineralocorticoid signaling might have developed during evolution of the loop of Henle, a well-known mammalian target for mineralocorticoids [61]. On the other hand, the essential function of vision-/brain-dependent behavior 
control that also occurs in mammals is mediated non-genomically as well as genomically [62], which suggests a corticosteroid function that is strongly conserved among vertebrates, including humans.

Author Contributions: T.S. prepared the original draft of the manuscript; H.S. critically reviewed the text and made scientific contributions. All authors approved the final version of the manuscript.

Funding: This research was funded by a Grant-in-Aid (15H04395).

Conflicts of Interest: The authors declare no conflict of interest.

\section{References}

1. Pfaff, D.W. Uptake of 3H-estradiol by the female rat brain. An autoradiographic study. Endocrinology 1968, 82, 1149-1155. [CrossRef] [PubMed]

2. Stumpf, W.E. Estradiol-concentrating neurons: Topography in the hypothalamus by dry-mount autoradiography. Science 1968, 162, 1001-1003. [CrossRef] [PubMed]

3. Michael, R.P. Estrogen-sensitive neurons and sexual behavior in female cats. Science 1962, 136, $322-323$. [CrossRef] [PubMed]

4. McEwen, B.S.; Davis, P.G.; Parsons, B.; Pfaff, D.W. The brain as a target for steroid hormone action. Annu. Rev. Neurosci. 1979, 2, 65-112. [CrossRef]

5. Balthazart, J.; Choleris, E.; Remage-Healey, L. Steroids and the brain: 50 Years of research, conceptual shifts and the ascent of non-classical and membrane-initiated actions. Horm. Behav. 2018, 99, 1-8. [CrossRef] [PubMed]

6. Sakamoto, H.; Takahashi, H.; Matsuda, K.; Nishi, M.; Takanami, K.; Ogoshi, M.; Sakamoto, T.; Kawata, M. Rapid signaling of steroid hormones in the vertebrate nervous system. Front. Biosci. (Landmark. Ed.) 2012, 17, 996-1019. [CrossRef] [PubMed]

7. Sakamoto, T.; Hyodo, S.; Takagi, W. A possible principal function of corticosteroid signaling that is conserved in vertebrate evolution: Lessons from receptor-knockout small fish. J. Steroid Biochem. Mol. Biol. 2018, 184, 57-61. [CrossRef]

8. Facchinello, N.; Skobo, T.; Meneghetti, G.; Colletti, E.; Dinarello, A.; Tiso, N.; Costa, R.; Gioacchini, G.; Carnevali, O.; Argenton, F.; et al. nr3c1 null mutant zebrafish are viable and reveal DNA-binding-independent activities of the glucocorticoid receptor. Sci. Rep. 2017, 7, 4371. [CrossRef]

9. Vettori, A.; Greenald, D.; Wilson, G.K.; Peron, M.; Facchinello, N.; Markham, E.; Sinnakaruppan, M.; Matthews, L.C.; McKeating, J.A.; Argenton, F.; et al. Glucocorticoids promote Von Hippel Lindau degradation and Hif-1alpha stabilization. Proc. Natl. Acad. Sci. USA 2017, 114, 9948-9953. [CrossRef]

10. Faught, E.; Vijayan, M.M. The mineralocorticoid receptor is essential for stress axis regulation in zebrafish larvae. Sci. Rep. 2018, 8, 18081. [CrossRef]

11. Ziv, L.; Muto, A.; Schoonheim, P.J.; Meijsing, S.H.; Strasser, D.; Ingraham, H.A.; Schaaf, M.J.; Yamamoto, K.R.; Baier, H. An affective disorder in zebrafish with mutation of the glucocorticoid receptor. Mol. Psychiatry 2013, 18, 681-691. [CrossRef]

12. Muto, A.; Taylor, M.R.; Suzawa, M.; Korenbrot, J.I.; Baier, H. Glucocorticoid receptor activity regulates light adaptation in the zebrafish retina. Front. Neural Circuits 2013, 7, 145. [CrossRef]

13. Sakamoto, T.; Yoshiki, M.; Takahashi, H.; Yoshida, M.; Ogino, Y.; Ikeuchi, T.; Nakamachi, T.; Konno, N.; Matsuda, K.; Sakamoto, H. Principal function of mineralocorticoid signaling suggested by constitutive knockout of the mineralocorticoid receptor in medaka fish. Sci. Rep. 2016, 6, 37991. [CrossRef] [PubMed]

14. Sakamoto, T.; Yoshiki, M.; Sakamoto, H. The mineralocorticoid receptor knockout in medaka is further validated by glucocorticoid receptor compensation. Sci. Data 2017, 4, 170189. [CrossRef]

15. Kolber, B.J.; Wieczorek, L.; Muglia, L.J. Hypothalamic-pituitary-adrenal axis dysregulation and behavioral analysis of mouse mutants with altered glucocorticoid or mineralocorticoid receptor function. Stress 2008, 11, 321-338. [CrossRef] [PubMed]

16. Ridder, S.; Chourbaji, S.; Hellweg, R.; Urani, A.; Zacher, C.; Schmid, W.; Zink, M.; Hortnagl, H.; Flor, H.; Henn, F.A.; et al. Mice with genetically altered glucocorticoid receptor expression show altered sensitivity for stress-induced depressive reactions. J. Neurosci. 2005, 25, 6243-6250. [CrossRef]

17. Whirledge, S.; DeFranco, D.B. Glucocorticoid Signaling in Health and Disease: Insights From Tissue-Specific GR Knockout Mice. Endocrinology 2018, 159, 46-64. [CrossRef] [PubMed] 
18. Boyle, M.P.; Brewer, J.A.; Funatsu, M.; Wozniak, D.F.; Tsien, J.Z.; Izumi, Y.; Muglia, L.J. Acquired deficit of forebrain glucocorticoid receptor produces depression-like changes in adrenal axis regulation and behavior. Proc. Natl. Acad. Sci. USA 2005, 102, 473-478. [CrossRef] [PubMed]

19. Tronche, F.; Kellendonk, C.; Kretz, O.; Gass, P.; Anlag, K.; Orban, P.C.; Bock, R.; Klein, R.; Schutz, G. Disruption of the glucocorticoid receptor gene in the nervous system results in reduced anxiety. Nat. Genet. 1999, 23, 99-103. [CrossRef] [PubMed]

20. Montkowski, A.; Barden, N.; Wotjak, C.; Stec, I.; Ganster, J.; Meaney, M.; Engelmann, M.; Reul, J.M.; Landgraf, R.; Holsboer, F. Long-term antidepressant treatment reduces behavioural deficits in transgenic mice with impaired glucocorticoid receptor function. J. Neuroendocrinol. 1995, 7, 841-845. [CrossRef]

21. Wei, Q.; Lu, X.Y.; Liu, L.; Schafer, G.; Shieh, K.R.; Burke, S.; Robinson, T.E.; Watson, S.J.; Seasholtz, A.F.; Akil, H. Glucocorticoid receptor overexpression in forebrain: A mouse model of increased emotional lability. Proc. Natl. Acad. Sci. USA 2004, 101, 11851-11856. [CrossRef]

22. Vaquero, C.F.; Pignatelli, A.; Partida, G.J.; Ishida, A.T. A dopamine- and protein kinase A-dependent mechanism for network adaptation in retinal ganglion cells. J. Neurosci. 2001, 21, 8624-8635. [CrossRef] [PubMed]

23. Witkovsky, P. Dopamine and retinal function. Doc. Ophthalmol. 2004, 108, 17-40. [CrossRef] [PubMed]

24. Li, L.; Dowling, J.E. Effects of dopamine depletion on visual sensitivity of zebrafish. J. Neurosci. 2000, 20, 1893-1903. [CrossRef]

25. Sulaiman, R.S.; Kadmiel, M.; Cidlowski, J.A. Glucocorticoid receptor signaling in the eye. Steroids 2018, 133, 60-66. [CrossRef] [PubMed]

26. Pecoraro, N.; Dallman, M.F.; Warne, J.P.; Ginsberg, A.B.; Laugero, K.D.; la Fleur, S.E.; Houshyar, H.; Gomez, F.; Bhargava, A.; Akana, S.F. From Malthus to motive: How the HPA axis engineers the phenotype, yoking needs to wants. Prog. Neurobiol. 2006, 79, 247-340. [CrossRef]

27. Watson, M.L.; Baehr, L.M.; Reichardt, H.M.; Tuckermann, J.P.; Bodine, S.C.; Furlow, J.D. A cell-autonomous role for the glucocorticoid receptor in skeletal muscle atrophy induced by systemic glucocorticoid exposure. Am. J. Physiol. Endocrinol. Metab. 2012, 302, E1210-E1220. [CrossRef]

28. Braun, T.P.; Szumowski, M.; Levasseur, P.R.; Grossberg, A.J.; Zhu, X.; Agarwal, A.; Marks, D.L. Muscle atrophy in response to cytotoxic chemotherapy is dependent on intact glucocorticoid signaling in skeletal muscle. PLoS ONE 2014, 9, e106489. [CrossRef]

29. Braun, T.P.; Grossberg, A.J.; Krasnow, S.M.; Levasseur, P.R.; Szumowski, M.; Zhu, X.X.; Maxson, J.E.; Knoll, J.G.; Barnes, A.P.; Marks, D.L. Cancer- and endotoxin-induced cachexia require intact glucocorticoid signaling in skeletal muscle. FASEB J. 2013, 27, 3572-3582. [CrossRef]

30. Brennan-Speranza, T.C.; Henneicke, H.; Gasparini, S.J.; Blankenstein, K.I.; Heinevetter, U.; Cogger, V.C.; Svistounov, D.; Zhang, Y.; Cooney, G.J.; Buttgereit, F.; et al. Osteoblasts mediate the adverse effects of glucocorticoids on fuel metabolism. J. Clin. Investig. 2012, 122, 4172-4189. [CrossRef]

31. Shimizu, N.; Maruyama, T.; Yoshikawa, N.; Matsumiya, R.; Ma, Y.; Ito, N.; Tasaka, Y.; Kuribara-Souta, A.; Miyata, K.; Oike, Y.; et al. A muscle-liver-fat signalling axis is essential for central control of adaptive adipose remodelling. Nat. Commun. 2015, 6, 6693. [CrossRef] [PubMed]

32. Cole, T.J.; Young, M.J. 30 YEARS OF THE MINERALOCORTICOID RECEPTOR: Mineralocorticoid receptor null mice: Informing cell-type-specific roles. J. Endocrinol. 2017, 234, T83-T92. [CrossRef] [PubMed]

33. Berger, S.; Bleich, M.; Schmid, W.; Cole, T.J.; Peters, J.; Watanabe, H.; Kriz, W.; Warth, R.; Greger, R.; Schutz, G. Mineralocorticoid receptor knockout mice: Pathophysiology of Na+ metabolism. Proc. Natl. Acad. Sci. USA 1998, 95, 9424-9429. [CrossRef] [PubMed]

34. Bleich, M.; Warth, R.; Schmidt-Hieber, M.; Schulz-Baldes, A.; Hasselblatt, P.; Fisch, D.; Berger, S.; Kunzelmann, K.; Kriz, W.; Schutz, G.; et al. Rescue of the mineralocorticoid receptor knock-out mouse. Pflugers Arch. 1999, 438, 245-254. [CrossRef] [PubMed]

35. Stolte, E.H.; de Mazon, A.F.; Leon-Koosterziel, K.M.; Jesiak, M.; Bury, N.R.; Sturm, A.; Savelkoul, H.F.; van Kemenade, B.M.; Flik, G. Corticosteroid receptors involved in stress regulation in common carp, Cyprinus carpio. J. Endocrinol. 2008, 198, 403-417. [CrossRef]

36. Northcutt, R.; Davis, R. Telencephalic organization in ray-finned fishes. Fish Neurobiol. 1983, 2, $203-236$.

37. Teitsma, C.A.; Anglade, I.; Lethimonier, C.; Le Drean, G.; Saligaut, D.; Ducouret, B.; Kah, O. Glucocorticoid receptor immunoreactivity in neurons and pituitary cells implicated in reproductive functions in rainbow trout: A double immunohistochemical study. Biol. Reprod. 1999, 60, 642-650. [CrossRef] 
38. Carruth, L.L.; Jones, R.E.; Norris, D.O. Cell density and intracellular translocation of glucocorticoid receptor-immunoreactive neurons in the kokanee salmon (Oncorhynchus nerka kennerlyi) brain, with an emphasis on the olfactory system. Gen. Comp. Endocrinol. 2000, 117, 66-76. [CrossRef]

39. Takahashi, H.; Sakamoto, T. The role of 'mineralocorticoids' in teleost fish: Relative importance of glucocorticoid signaling in the osmoregulation and 'central' actions of mineralocorticoid receptor. Gen. Comp. Endocrinol. 2013, 181, 223-228. [CrossRef]

40. Baker, M.E.; Katsu, Y. 30 YEARS OF THE MINERALOCORTICOID RECEPTOR: Evolution of the mineralocorticoid receptor: Sequence, structure and function. J. Endocrinol. 2017, 234, T1-T16. [CrossRef]

41. Geerling, J.C.; Loewy, A.D. Aldosterone in the brain. Am. J. Physiol. Ren. Physiol. 2009, 297, F559-F576. [CrossRef]

42. Funder, J.W.; Pearce, P.T.; Smith, R.; Smith, A.I. Mineralocorticoid action: Target tissue specificity is enzyme, not receptor, mediated. Science 1988, 242, 583-585. [CrossRef] [PubMed]

43. Alderman, S.L.; Vijayan, M.M. 11beta-hydroxysteroid dehydrogenase type 2 in zebrafish brain: A functional role in HPI axis regulation. J. Endocrinol. 2012. [CrossRef] [PubMed]

44. de Kloet, E.R.; Van Acker, S.A.; Sibug, R.M.; Oitzl, M.S.; Meijer, O.C.; Rahmouni, K.; de Jong, W. Brain mineralocorticoid receptors and centrally regulated functions. Kidney Int. 2000, 57, 1329-1336. [CrossRef] [PubMed]

45. Oitzl, M.S.; de Kloet, E.R. Selective corticosteroid antagonists modulate specific aspects of spatial orientation learning. Behav. Neurosci. 1992, 106, 62-71. [CrossRef] [PubMed]

46. Souza, R.R.; Dal Bo, S.; de Kloet, E.R.; Oitzl, M.S.; Carobrez, A.P. Paradoxical mineralocorticoid receptor-mediated effect in fear memory encoding and expression of rats submitted to an olfactory fear conditioning task. Neuropharmacology 2014, 79, 201-211. [CrossRef]

47. de Kloet, E.R.; Joels, M. Brain mineralocorticoid receptor function in control of salt balance and stress-adaptation. Physiol. Behav. 2017, 178, 13-20. [CrossRef]

48. Schwabe, L.; Tegenthoff, M.; Hoffken, O.; Wolf, O.T. Mineralocorticoid receptor blockade prevents stress-induced modulation of multiple memory systems in the human brain. Biol. Psychiatry 2013, 74, 801-808. [CrossRef]

49. Conrad, C.D.; Lupien, S.J.; Thanasoulis, L.C.; McEwen, B.S. The effects of type I and type II corticosteroid receptor agonists on exploratory behavior and spatial memory in the Y-maze. Brain Res. 1997, 759, 76-83. [CrossRef]

50. Douma, B.R.; Korte, S.M.; Buwalda, B.; la Fleur, S.E.; Bohus, B.; Luiten, P.G. Repeated blockade of mineralocorticoid receptors, but not of glucocorticoid receptors impairs food rewarded spatial learning. Psychoneuroendocrinology 1998, 23, 33-44. [CrossRef]

51. Joels, M.; de Kloet, E.R. 30 YEARS OF THE MINERALOCORTICOID RECEPTOR: The brain mineralocorticoid receptor: A saga in three episodes. J. Endocrinol. 2017, 234, T49-T66. [CrossRef] [PubMed]

52. Yau, J.L.; Noble, J.; Seckl, J.R. Continuous blockade of brain mineralocorticoid receptors impairs spatial learning in rats. Neurosci. Lett. 1999, 277, 45-48. [CrossRef]

53. Ratka, A.; Sutanto, W.; Bloemers, M.; de Kloet, E.R. On the role of brain mineralocorticoid (type I) and glucocorticoid (type II) receptors in neuroendocrine regulation. Neuroendocrinology 1989, 50, 117-123. [CrossRef] [PubMed]

54. Rozeboom, A.M.; Akil, H.; Seasholtz, A.F. Mineralocorticoid receptor overexpression in forebrain decreases anxiety-like behavior and alters the stress response in mice. Proc. Natl. Acad. Sci. USA 2007, 104, 4688-4693. [CrossRef] [PubMed]

55. Roberts, J.E. Light and immunomodulation. Ann. N. Y. Acad. Sci. 2000, 917, 435-445. [CrossRef] [PubMed]

56. Lefevre, F.; Cos, I.; Pottinger, T.G.; Bugeon, J. Selection for stress responsiveness and slaughter stress affect flesh quality in pan-size rainbow trout, Oncorhynchus mykiss. Aquaculture 2016, 464, 654-664. [CrossRef]

57. Presman, D.M.; Ogara, M.F.; Stortz, M.; Alvarez, L.D.; Pooley, J.R.; Schiltz, R.L.; Grontved, L.; Johnson, T.A.; Mittelstadt, P.R.; Ashwell, J.D.; et al. Live cell imaging unveils multiple domain requirements for in vivo dimerization of the glucocorticoid receptor. PLoS Biol. 2014, 12, e1001813. [CrossRef] [PubMed]

58. Jewell, C.M.; Scoltock, A.B.; Hamel, B.L.; Yudt, M.R.; Cidlowski, J.A. Complex human glucocorticoid receptor dim mutations define glucocorticoid induced apoptotic resistance in bone cells. Mol. Endocrinol. 2012, 26, 244-256. [CrossRef] 
59. DeMayo, F.J.; Spencer, T.E. CRISPR bacon: A sizzling technique to generate genetically engineered pigs. Biol. Reprod. 2014, 91, 79. [CrossRef]

60. Ma, H.; Marti-Gutierrez, N.; Park, S.W.; Wu, J.; Lee, Y.; Suzuki, K.; Koski, A.; Ji, D.; Hayama, T.; Ahmed, R.; et al. Correction of a pathogenic gene mutation in human embryos. Nature 2017, 548, 413-419. [CrossRef]

61. Dietl, P.; Good, D.; Stanton, B. Adrenal corticosteroid action on the thick ascending limb. Semin. Nephrol. 1990, 10, 350-364. [PubMed]

62. Gray, J.D.; Kogan, J.F.; Marrocco, J.; McEwen, B.S. Genomic and epigenomic mechanisms of glucocorticoids in the brain. Nat. Rev. Endocrinol. 2017, 13, 661-673. [CrossRef] [PubMed]

(C) 2019 by the authors. Licensee MDPI, Basel, Switzerland. This article is an open access article distributed under the terms and conditions of the Creative Commons Attribution (CC BY) license (http:/ / creativecommons.org/licenses/by/4.0/). 